\section{Distribution of Persea schiedeana in Mexico and Potential for the Production of Fruits with High-quality Oil}

\author{
Juan Guillermo Cruz-Castillo ${ }^{1}$ and Juan Ángel Tinoco-Rueda \\ Centro Regional Universitario Oriente, Universidad Autónoma Chapingo, \\ Huatusco, Veracruz 94100, México
}

\section{Franco Famiani ${ }^{1}$ \\ Dipartimento di Scienze Agrarie, Alimentari e Ambientali, Università degli Studi di Perugia, Borgo XX Giugno 74, 06121 Perugia, Italy}

Additional index words. chinene, ecological niche, underutilized fruit, zoning, Mesoamerican fruit

\begin{abstract}
The fruit of Persea schiedeana is consumed in various rural regions of Mexico and Central America and is mainly sold in local markets. Information regarding the ecological conditions where it grows and the potential for its distribution in Mexico has been little studied. The States of Chiapas, Hidalgo, Oaxaca, Puebla, Tabasco, and Veracruz in Mexico were explored to locate $P$. schiedeana trees. The ecological conditions of the places where $P$. schiedeana was found were characterized using thematic cartography and by evaluating the ecological niches to identify potential areas for its distribution. The trees were found in wide physiographic, geological, and edaphic conditions, but they were primarily located in semiwarm humid and warm humid climates. Persea schiedeana trees grow from almost sea level to $2000 \mathrm{~m}$ in altitude. Zones with the best developmental conditions for $P$. schiedeana were in the region of the high mountains in the center of Veracruz and the highland zone of northern Oaxaca. The oil obtained from the fruit of $P$. schiedeana trees growing at $1300 \mathrm{~m}$ had high oleic acid content. This wild fruit has the potential for obtaining new products for cosmetic and alimentary industries.
\end{abstract}

Persea schiedeana Nees., a fruit tree native to Mexico and Central America, belongs to the Lauraceae family (GalindoTovar et al., 2008). In Mexico it is called "chinene" or "chinin" and in Guatemala "chucte." Trees can reach $25 \mathrm{~m}$ in height and the size and shape of the fruit resemble avocado (Persea americana Mill). It is attractive as a fresh product. In Mexico it is consumed by spreading the pulp of the fruit on maize tortillas and in Guatemala by adding the pulp to black bean soup. It is also a popular food in Honduras and El Salvador.

There are no commercial orchards of $P$. schiedeana in Mexico and Central America; however, in Oaxaca, Mexico, trees are artificially irrigated in home gardens during the dry season (Gómez-Pompa et al., 2010). Persea schiedeana grows wild mainly in the Mexican states of Oaxaca, Puebla, Tabasco, and Veracruz (GBIF, 2013; Joaquín-Martínez et al., 2007; Sánchez-Pérez, 1999). Fruit collected in the rainforest and/or home gardens can be found in regional markets of Veracruz, Mexico (Ibarra-Manríquez et al., 1997), and

Received for publication 7 Oct. 2016. Accepted for publication 23 Jan. 2017.

${ }^{1}$ Corresponding authors. E-mail: jcruzcastillo@ yahoo.com or franco.famiani@unipg.it.
Guatemala between June and September. In Cuetzalan del Progreso, Puebla, Mexico, the fruit is sold in the local market without its seed, and is called "chinene capado" (seedless chinene). Mammalian fauna in coffee plantations consume $P$. schiedeana fruit and the tree provides shelter and protection from predators (Gallina et al., 1996). In avocado production, 'Martin Grande', a hybrid between $P$. schiedeana and $P$. americana, has been tested as a rootstock to combat phytophthora

Persea schiedeana trees are used for shade in coffee plantations in Veracruz, Puebla, and Oaxaca, Mexico (Bost, 2014; Del AngelCoronel et al., 2010), and they have been determined satisfactory for carbon sequestration in the highlands of Veracruz, Mexico (MelchorMarroquín et al., 2014). However, there is little information regarding the soil and climatic conditions where $P$. schiedeana grows, and the potential areas where $P$. schiedeana could achieve high fruit yield are unknown.

There are no registered cultivars of $P$. schiedeana for human consumption. An increase in the fruit production of $P$. schiedeana with selected trees has been recommended to improve food security, and the economy of local agriculture in the tropics of Mexico and Central America (Bost, 2014).

Persea schiedeana is a climacteric fruit with a postharvest life span of only 3-5 d root rot (Coffey et al., 1988).
(Del-Angel-Coronel et al., 2010). Thus, processing the fruit pulp could be an option for extending its use and making it available for consumers. The fruit oil potential of $P$. schiedeana has been demonstrated in a few studies (Cruz-Castillo et al., 2007; JoaquínMartínez et al., 2007), but the concentrations of the main fatty acids of the oil need to be confirmed.

The aims of the present study were to determine the environmental characteristics where $P$. schiedeana grows and its potential for distribution in Mexico, and to demonstrate the capacity of the tree for production of fruits with high-quality oil.

\section{Materials and Methods}

Localization of $\mathrm{P}$. schiedeana in six states of Mexico. General indications about places where $P$. schiedeana has been reported were obtained from the herbarium of the National Institute of Ecology in Xalapa, in Veracruz, Mexico. Those places as well as nearby areas were explored. The trees found were localized using a GPS-12 Channel Garmin personal navigator, which gave the exact latitude $(\mathrm{N})$, longitude $(\mathrm{W})$, and altitude $(\mathrm{m})$. Persea schiedeana trees (n. 146) were georeferenced in the states of Oaxaca, Veracruz, Tabasco, Puebla, Hidalgo, and Chiapas. A maximum of three trees per municipality are shown in Table 1.

Ecological characterization and zoning. The ecological conditions of the sites georeferenced for the presence of $P$. schiedeana trees were characterized using the cartographic analysis of thematical and digital maps obtained from the National Institute of Statistics and Geography (INEGI, 2002, 2004, 2006, 2014) and from the Autonomous University of Chapingo, Mexico (Gómez et al., 2006).

For each georeferenced tree, information regarding the physiographic province, type of rock, soil type and texture, mean monthly temperature, mean yearly temperature, average monthly and average annual precipitation, and climate was obtained using ArcMap $^{\circledR}$ modified by Köppen. With this information, a geographic database was elaborated to describe the habitat of $P$. schiedeana.

A cluster analysis using climatic and soil data was performed using the Ward method (Di Rienzo et al., 2016), and groups with homogeneous distribution of $P$. schiedeana trees in zones of Mexico were identified (Núñez, 2010). With the records of precipitation and mean monthly temperatures in each cluster, a climograph was generated and the climatic classification was obtained according to the system of Köppen modified by García (1988)

Potential for distribution. The DIVAGIS $^{\circledR}$ software was used to develop a climatic model for the potential distribution of $P$. schiedeana in Mexico using georeferenced trees and the database of WorldClim with a spatial resolution of $2.5 \mathrm{~min}$. The potential distribution of $P$. schiedeana was made on 
Table 1. Coordinates [latitude (N), longitude (W)] of Persea schiedeana trees (n. 88) located in municipalities of six Mexican states. A maximum of three trees per municipality are shown.

\begin{tabular}{|c|c|c|c|c|}
\hline ID & State & Municipality & Latitude & Longitude \\
\hline 1 & Oaxaca & Chinantla & $17^{\circ} 44^{\prime} 24.6^{\prime \prime}$ & $-96^{\circ} 33^{\prime} 31.6^{\prime \prime}$ \\
\hline 2 & Oaxaca & Chinantla & $17^{\circ} 44^{\prime} 24.6^{\prime \prime}$ & $-96^{\circ} 33^{\prime} 31.5^{\prime \prime}$ \\
\hline 3 & Oaxaca & Chinantla & $17^{\circ} 44^{\prime} 22.8^{\prime \prime}$ & $-96^{\circ} 33^{\prime} 31.5^{\prime \prime}$ \\
\hline 4 & Oaxaca & Santa Catarina Juquila & $16^{\circ} 44^{\prime} 22.3^{\prime \prime}$ & $-97^{\circ} 17^{\prime} 40.6^{\prime \prime}$ \\
\hline 5 & Oaxaca & Candelaria Loxicha & $15^{\circ} 57^{\prime} 16.2^{\prime \prime}$ & $-96^{\circ} 28^{\prime} 46^{\prime \prime}$ \\
\hline 6 & Oaxaca & Candelaria Loxicha & $15^{\circ} 57^{\prime} 17.1^{\prime \prime}$ & $-96^{\circ} 28^{\prime} 44.6^{\prime \prime}$ \\
\hline 7 & Oaxaca & Pluma Hidalgo & $15^{\circ} 56^{\prime} 40.7^{\prime \prime}$ & $-96^{\circ} 24^{\prime} 5.3^{\prime \prime}$ \\
\hline 8 & Oaxaca & Santiago Comaltepec & $17^{\circ} 36^{\prime} 2.2^{\prime \prime}$ & $-96^{\circ} 25^{\prime} 3^{\prime \prime}$ \\
\hline 9 & Oaxaca & Santiago Comaltepec & $17^{\circ} 37^{\prime} 55^{\prime \prime}$ & $-96^{\circ} 20^{\prime} 33.1^{\prime \prime}$ \\
\hline 10 & Oaxaca & Santiago Comaltepec & $17^{\circ} 42^{\prime} 25^{\prime \prime}$ & $-96^{\circ} 17^{\prime} 59^{\prime \prime}$ \\
\hline 11 & Oaxaca & S. Juan Bautista Tuxtepec & $17^{\circ} 45^{\prime} 18.8^{\prime \prime}$ & $-96^{\circ} 19^{\prime} 9^{\prime \prime}$ \\
\hline 12 & Oaxaca & S. Juan Bautista Tuxtepec & $17^{\circ} 48^{\prime} 30^{\prime \prime}$ & $-96^{\circ} 19^{\prime} 30^{\prime \prime}$ \\
\hline 13 & Oaxaca & S. Juan Bautista Tuxtepec & $17^{\circ} 49^{\prime} 50.7^{\prime \prime}$ & $-96^{\circ} 19^{\prime} 51.5^{\prime \prime}$ \\
\hline 14 & Oaxaca & Guevea de Humbolt & $16^{\circ} 48^{\prime} 7.2^{\prime \prime}$ & $-95^{\circ} 22^{\prime} 25.1^{\prime \prime}$ \\
\hline 15 & Oaxaca & San Bartolomé Zoogocho & $17^{\circ} 17^{\prime} 2^{\prime \prime}$ & $-96^{\circ} 13^{\prime} 21^{\prime \prime}$ \\
\hline 16 & Oaxaca & Tanetze de Zaragoza & $17^{\circ} 22^{\prime} 6^{\prime \prime}$ & $-96^{\circ} 17^{\prime} 54^{\prime \prime}$ \\
\hline 17 & Oaxaca & Tanetze de Zaragoza & $17^{\circ} 22^{\prime} 40^{\prime \prime}$ & $-96^{\circ} 17^{\prime} 52^{\prime \prime}$ \\
\hline 18 & Oaxaca & San Juan Yaee & $17^{\circ} 25^{\prime} 36^{\prime \prime}$ & $-96^{\circ} 17^{\prime} 2^{\prime \prime}$ \\
\hline 19 & Oaxaca & Villa Talea de Castro & $17^{\circ} 23^{\prime} 3^{\prime \prime}$ & $-96^{\circ} 16^{\prime} 8^{\prime \prime}$ \\
\hline 20 & Oaxaca & Villa Talea de Castro & $17^{\circ} 23^{\prime} 2^{\prime \prime}$ & $-96^{\circ} 16^{\prime} 8^{\prime \prime}$ \\
\hline 21 & Oaxaca & Santiago Lalopa & $17^{\circ} 25^{\prime} 20^{\prime \prime}$ & $-96^{\circ} 13^{\prime} 30^{\prime \prime}$ \\
\hline 22 & Oaxaca & Santiago Lalopa & $17^{\circ} 24^{\prime} 29^{\prime \prime}$ & $-96^{\circ} 15^{\prime} 23^{\prime \prime}$ \\
\hline 23 & Oaxaca & San Juan Lachao & $16^{\circ} 10^{\prime} 9^{\prime \prime}$ & $-97^{\circ} 5^{\prime} 43^{\prime \prime}$ \\
\hline 24 & Oaxaca & San Gabriel Mixtepec & $16^{\circ} 5^{\prime} 47^{\prime \prime}$ & $-97^{\circ} 5^{\prime} 43^{\prime \prime}$ \\
\hline 25 & Oaxaca & San Gabriel Mixtepec & $16^{\circ} 4^{\prime} 29^{\prime \prime}$ & $-97^{\circ} 4^{\prime} 8^{\prime \prime}$ \\
\hline 26 & Oaxaca & San Gabriel Mixtepec & $16^{\circ} 4^{\prime} 25^{\prime \prime}$ & $-97^{\circ} 4^{\prime} 4^{\prime \prime}$ \\
\hline 27 & Veracruz & Orizaba & $18^{\circ} 51^{\prime} 26.6^{\prime \prime}$ & $-97^{\circ} 4^{\prime} 22.4^{\prime \prime}$ \\
\hline 28 & Veracruz & Orizaba & $18^{\circ} 51^{\prime} 27.2^{\prime \prime}$ & $-97^{\circ} 4^{\prime} 23.3^{\prime \prime}$ \\
\hline 29 & Veracruz & Orizaba & $18^{\circ} 51^{\prime} 20.1^{\prime \prime}$ & $-97^{\circ} 4^{\prime} 24.3^{\prime \prime}$ \\
\hline 30 & Veracruz & Cuichapa & $18^{\circ} 46^{\prime} 24.5^{\prime \prime}$ & $-96^{\circ} 52^{\prime} 15.3^{\prime \prime}$ \\
\hline 31 & Veracruz & Cuichapa & $18^{\circ} 46^{\prime} 17.3^{\prime \prime}$ & $-96^{\circ} 52^{\prime} 16.2^{\prime \prime}$ \\
\hline 32 & Veracruz & Cuichapa & $18^{\circ} 46^{\prime} 15.2^{\prime \prime}$ & $-96^{\circ} 52^{\prime} 12.3^{\prime \prime}$ \\
\hline 33 & Veracruz & Amatlan de los Reyes & $18^{\circ} 51^{\prime} 18.5^{\prime \prime}$ & $-96^{\circ} 54^{\prime} 47.7^{\prime \prime}$ \\
\hline 34 & Veracruz & Tezonapa & $18^{\circ} 33^{\prime} 20.4^{\prime \prime}$ & $-96^{\circ} 43^{\prime} 6.3^{\prime \prime}$ \\
\hline 35 & Veracruz & Tezonapa & $18^{\circ} 32^{\prime} 27.2^{\prime \prime}$ & $-96^{\circ} 46^{\prime} 6.3^{\prime \prime}$ \\
\hline 36 & Veracruz & Tezonapa & $18^{\circ} 32^{\prime} 21^{\prime \prime}$ & $-96^{\circ} 46^{\prime} 7.9^{\prime \prime}$ \\
\hline 37 & Veracruz & Huayacocotla & $20^{\circ} 33^{\prime} 44.4^{\prime \prime}$ & $-98^{\circ} 26^{\prime} 36.2^{\prime \prime}$ \\
\hline 38 & Veracruz & Huayacocotla & $20^{\circ} 33^{\prime} 44^{\prime \prime}$ & $-98^{\circ} 26^{\prime} 36.9^{\prime \prime}$ \\
\hline 39 & Veracruz & Huayacocotla & $20^{\circ} 33^{\prime} 43.8^{\prime \prime}$ & $-98^{\circ} 26^{\prime} 36.9^{\prime \prime}$ \\
\hline 40 & Veracruz & Ixhuatlán del Café & $19^{\circ} 2^{\prime} 20.7^{\prime \prime}$ & $-96^{\circ} 55^{\prime} 23.3^{\prime \prime}$ \\
\hline 41 & Veracruz & Ixtaczoquitlan & $18^{\circ} 52^{\prime} 23.8^{\prime \prime}$ & $-97^{\circ} 1^{\prime} 42.9^{\prime \prime}$ \\
\hline 42 & Veracruz & Ixtaczoquitlan & $18^{\circ} 52^{\prime} 21.1^{\prime \prime}$ & $-97^{\circ} 1^{\prime} 40.7^{\prime \prime}$ \\
\hline 43 & Veracruz & Ixtaczoquitlan & $18^{\circ} 52^{\prime} 21.6^{\prime \prime}$ & $-97^{\circ} 1^{\prime} 44.3^{\prime \prime}$ \\
\hline 44 & Veracruz & Huatusco & $19^{\circ} 9^{\prime} 14.8^{\prime \prime}$ & $-96^{\circ} 58^{\prime} 29.8^{\prime \prime}$ \\
\hline 45 & Veracruz & Huatusco & $19^{\circ} 9^{\prime} 15^{\prime \prime}$ & $-96^{\circ} 58^{\prime} 30.6^{\prime \prime}$ \\
\hline 46 & Veracruz & Huatusco & $19^{\circ} 9^{\prime} 16.7^{\prime \prime}$ & $-96^{\circ} 58^{\prime} 33.8^{\prime \prime}$ \\
\hline 47 & Veracruz & Tlaltetela & $19^{\circ} 18^{\prime} 57.5^{\prime \prime}$ & $-96^{\circ} 54^{\prime} 26.8^{\prime \prime}$ \\
\hline 48 & Veracruz & Omealca & $18^{\circ} 45^{\prime} 46.1^{\prime \prime}$ & $-96^{\circ} 49^{\prime} 31.6^{\prime \prime}$ \\
\hline 49 & Veracruz & Omealca & $18^{\circ} 45^{\prime} 42.1^{\prime \prime}$ & $-96^{\circ} 49^{\prime} 26.4^{\prime \prime}$ \\
\hline 50 & Veracruz & Omealca & $18^{\circ} 45^{\prime} 36^{\prime \prime}$ & $-96^{\circ} 49^{\prime} 7^{\prime \prime}$ \\
\hline 51 & Veracruz & Juchique de Ferrer & $19^{\circ} 49^{\prime} 48.4^{\prime \prime}$ & $-96^{\circ} 41^{\prime} 6.4^{\prime \prime}$ \\
\hline 52 & Veracruz & Juchique de Ferrer & $19^{\circ} 47^{\prime} 39.2^{\prime \prime}$ & $-96^{\circ} 40^{\prime} 49.2^{\prime \prime}$ \\
\hline 53 & Veracruz & Juchique de Ferrer & $19^{\circ} 47^{\prime} 22^{\prime \prime}$ & $-96^{\circ} 41^{\prime} 30.8^{\prime \prime}$ \\
\hline 54 & Veracruz & Chiconquiaco & $19^{\circ} 43^{\prime} 47.2^{\prime \prime}$ & $-96^{\circ} 43^{\prime} 30.4^{\prime \prime}$ \\
\hline 55 & Veracruz & Chiconquiaco & $19^{\circ} 43^{\prime} 44.5^{\prime \prime}$ & $-96^{\circ} 43^{\prime} 35.3^{\prime \prime}$ \\
\hline 56 & Veracruz & Chiconquiaco & $19^{\circ} 43^{\prime} 39.5^{\prime \prime}$ & $-96^{\circ} 43^{\prime} 29.4^{\prime \prime}$ \\
\hline 57 & Tabasco & Nacajuca & $18^{\circ} 7^{\prime} 9^{\prime \prime}$ & $-93^{\circ} 22^{\prime} 1^{\prime \prime}$ \\
\hline 58 & Puebla & Cuetzalan & $20^{\circ} 2^{\prime} 9.3^{\prime \prime}$ & $-97^{\circ} 32^{\prime} 12.2^{\prime \prime}$ \\
\hline 59 & Puebla & Cuetzalan & $20^{\circ} 2^{\prime} 27.2^{\prime \prime}$ & $-97^{\circ} 32^{\prime} 10.8^{\prime \prime}$ \\
\hline 60 & Puebla & Cuetzalan & $20^{\circ} 3^{\prime} 18.6^{\prime \prime}$ & $-97^{\circ} 32^{\prime} 13.9^{\prime \prime}$ \\
\hline 61 & Puebla & Tlatlauquitepec & $19^{\circ} 55^{\prime} 49^{\prime \prime}$ & $-97^{\circ} 55^{\prime} 19.2^{\prime \prime}$ \\
\hline 62 & Puebla & Tlatlauquitepec & $19^{\circ} 55^{\prime} 5.3^{\prime \prime}$ & $-97^{\circ} 27.1^{\prime} 24^{\prime \prime}$ \\
\hline 63 & Puebla & Ahuacatlan & $20^{\circ} 0^{\prime} 18.51^{\prime \prime}$ & $-97^{\circ} 51^{\prime} 35.66^{\prime \prime}$ \\
\hline 64 & Puebla & Jalapan & $20^{\circ} 25^{\prime} 54.69^{\prime \prime}$ & $-97^{\circ} 51^{\prime} 8.65^{\prime \prime}$ \\
\hline 65 & Puebla & Jalapan & $20^{\circ} 24^{\prime} 20.25^{\prime \prime}$ & $-97^{\circ} 52^{\prime} 31.08^{\prime \prime}$ \\
\hline 66 & Puebla & Xicotepec & $20^{\circ} 16^{\prime} 2.15^{\prime \prime}$ & $-97^{\circ} 57^{\prime} 32.02^{\prime \prime}$ \\
\hline 67 & Puebla & Xicotepec & $20^{\circ} 15^{\prime} 56.61^{\prime \prime}$ & $-97^{\circ} 57^{\prime} 51.45^{\prime \prime}$ \\
\hline 68 & Puebla & Zihuatehutla & $20^{\circ} 15^{\prime} 33.97^{\prime \prime}$ & $-97^{\circ} 51^{\prime} 15.8^{\prime \prime}$ \\
\hline 69 & Puebla & Zihuatehutla & $20^{\circ} 17^{\prime} 20.98^{\prime \prime}$ & $-97^{\circ} 47^{\prime} 16.15^{\prime \prime}$ \\
\hline 70 & Puebla & Zongozotla & $19^{\circ} 59^{\prime} 14.16^{\prime \prime}$ & $-97^{\circ} 43^{\prime} 55.08^{\prime \prime}$ \\
\hline 71 & Chiapas & Ixtacomitan & $17^{\circ} 27^{\prime} 34.3^{\prime \prime}$ & $-93^{\circ} 6^{\prime} 4^{\prime \prime}$ \\
\hline 72 & Chiapas & Ixtacomitan & $17^{\circ} 25^{\prime} 37.3^{\prime \prime}$ & $-93^{\circ} 6^{\prime} 13.8^{\prime \prime}$ \\
\hline 73 & Chiapas & Ixtacomitan & $17^{\circ} 22^{\prime} 8.4^{\prime \prime}$ & $-93^{\circ} 6^{\prime} 35^{\prime \prime}$ \\
\hline
\end{tabular}

(Continued on next page) the basis of the ecological niche method (Hijmans et al., 2005) and only data regarding precipitation and temperatures were used.

Fatty acid profile of the oil. The fatty acid composition of the oils from $P$. schiedeana pulp was evaluated in 2015 on oils extracted from fruit of three different trees growing wild in the central part of the state of Veracruz at an altitude of $1300 \mathrm{~m}$. The trees were selected due to the good flavor of the pulp according to growers, and all the fruit had black skin. All the fruit was analyzed at consumption maturity. The fresh weight of the samples was between 190 and $267 \mathrm{~g}$. The seedling trees were about 30 years old and 20-25 m high. A completely randomized design was conducted using each tree as a treatment with 10 fruits per tree as replications. Analysis of variance was performed and the comparison of means was carried out using the Tukey's test (0.05) (Di Rienzo et al., 2016).

The oil was extracted using chloroform and methanol following the methodology described by Joaquín-Martínez et al. (2007). The fatty acid composition of the oil was determined as in Portarena et al. (2015). Fatty acids were converted to methyl esters before analysis by shaking a solution of $0.2 \mathrm{~g}$ oil and $3 \mathrm{~mL}$ of hexane with $0.4 \mathrm{~mL}$ of $2 \mathrm{~N}$ methanolic potassium hydroxide. After separation through a $100 \%$ dimethyl-polysiloxane VFwax Varian column ( $30 \mathrm{~m}$ length, $0.25 \mathrm{~mm}$ i.d., and $0.25 \mu \mathrm{m}$ film thickness) with a split/ splitless injector (1/10 ratio), the methyl esters were analyzed using a GC-FID detector. The temperatures of the injector and detector were held at 220 and $250{ }^{\circ} \mathrm{C}$, respectively. The injection volume was $1 \mu \mathrm{L}$. Preliminary peak identification was carried out by comparison of retention times with known standards. Fatty acids were designated according to standard notation (total number of carbon atoms: number of double bonds, followed by the position of the double bond from the methyl end of the molecule) as described by Peacock et al. (2001).

\section{Results and Discussion}

Ecological characterization. The spatial distribution of $P$. schiedeana trees was positioned between the maximum coordinates $20^{\circ} 50^{\prime} 24^{\prime \prime}$ and $15^{\circ} 56^{\prime} 42^{\prime \prime}$ north latitude, and $98^{\circ} 37^{\prime} 4.8^{\prime \prime}$ and $92^{\circ} 59^{\prime} 49.2^{\prime \prime}$ west longitude in Mexico. The altitudinal range of the trees was between $4 \mathrm{~m}$ (Nacajuca, Tabasco) and $2147 \mathrm{~m}$ (Chinantla, Oaxaca). The distribution of $P$. schiedeana in Mexico had a greater range as compared with that indicated by Sánchez-Pérez (1999), who established the presence of $P$. schiedeana primarily in the states of Veracruz and Tabasco. With the system of global biodiversity information facility (GBIF, 2013), $P$. schiedeana was located in San Luis Potosi, northeastern Chiapas, and southern Quintana Roo, Mexico. Likewise, Joaquín-Martínez et al. (2007) recorded the presence of $P$. schiedeana in Tuxtlas, Veracruz, Mexico, in plant communities of tall evergreen jungles, 
Table 1. (Continued) Coordinates [latitude (N), longitude (W)] of Persea schiedeana trees (n. 88) located in municipalities of six Mexican states. A maximum of three trees per municipality are shown.

\begin{tabular}{|c|c|c|c|c|}
\hline ID & State & Municipality & Latitude & Longitude \\
\hline$\overline{74}$ & Chiapas & Chapultenango & $17^{\circ} 19^{\prime} 16.2^{\prime \prime}$ & $-93^{\circ} 9^{\prime} 31.3^{\prime \prime}$ \\
\hline 75 & Chiapas & Chapultenango & $17^{\circ} 18^{\prime} 31.8^{\prime \prime}$ & $-93^{\circ} 9^{\prime} 56.2^{\prime \prime}$ \\
\hline 76 & Chiapas & Chapultenango & $17^{\circ} 18^{\prime} 31.9^{\prime \prime}$ & $-93^{\circ} 10^{\prime} 55.8^{\prime \prime}$ \\
\hline 77 & Chiapas & Francisco León & $17^{\circ} 17^{\prime} 29.4^{\prime \prime}$ & $-93^{\circ} 12^{\prime} 28.3^{\prime \prime}$ \\
\hline 78 & Chiapas & Francisco León & $17^{\circ} 17^{\prime} 25.1^{\prime \prime}$ & $-93^{\circ} 12^{\prime} 31.7^{\prime \prime}$ \\
\hline 79 & Chiapas & Francisco León & $17^{\circ} 17^{\prime} 20.8^{\prime \prime}$ & $-93^{\circ} 12^{\prime} 40.6^{\prime \prime}$ \\
\hline 80 & Chiapas & Tecpatan & $17^{\circ} 13^{\prime} 7.1^{\prime \prime}$ & $-93^{\circ} 20^{\prime} 31.1^{\prime \prime}$ \\
\hline 81 & Chiapas & Copainala & $17^{\circ} 7^{\prime} 36.2^{\prime \prime}$ & $-93^{\circ} 16^{\prime} 20.5^{\prime \prime}$ \\
\hline 82 & Chiapas & Copainala & $17^{\circ} 7^{\prime} 33.3^{\prime \prime}$ & $-93^{\circ} 15^{\prime} 49.1^{\prime \prime}$ \\
\hline 83 & Hidalgo & Xochicoatlan & $20^{\circ} 50^{\prime} 23.4^{\prime \prime}$ & $-98^{\circ} 36^{\prime} 56^{\prime \prime}$ \\
\hline 84 & Hidalgo & Xochicoatlan & $20^{\circ} 50^{\prime} 23.6^{\prime \prime}$ & $-98^{\circ} 36^{\prime} 56.93^{\prime \prime}$ \\
\hline 85 & Hidalgo & Xochicoatlan & $20^{\circ} 50^{\prime} 23.2^{\prime \prime}$ & $-98^{\circ} 36^{\prime} 56.3^{\prime \prime}$ \\
\hline 86 & Hidalgo & Tianguistengo & $20^{\circ} 50^{\prime} 6.2^{\prime \prime}$ & $-98^{\circ} 35^{\prime} 32.1^{\prime \prime}$ \\
\hline 87 & Hidalgo & Tianguistengo & $20^{\circ} 50^{\prime} 12.7^{\prime \prime}$ & $-98^{\circ} 35^{\prime} 22.9^{\prime \prime}$ \\
\hline 88 & Hidalgo & Tianguistengo & $20^{\circ} 50^{\prime} 13.02^{\prime \prime}$ & $-98^{\circ} 35^{\prime} 22.4^{\prime \prime}$ \\
\hline
\end{tabular}

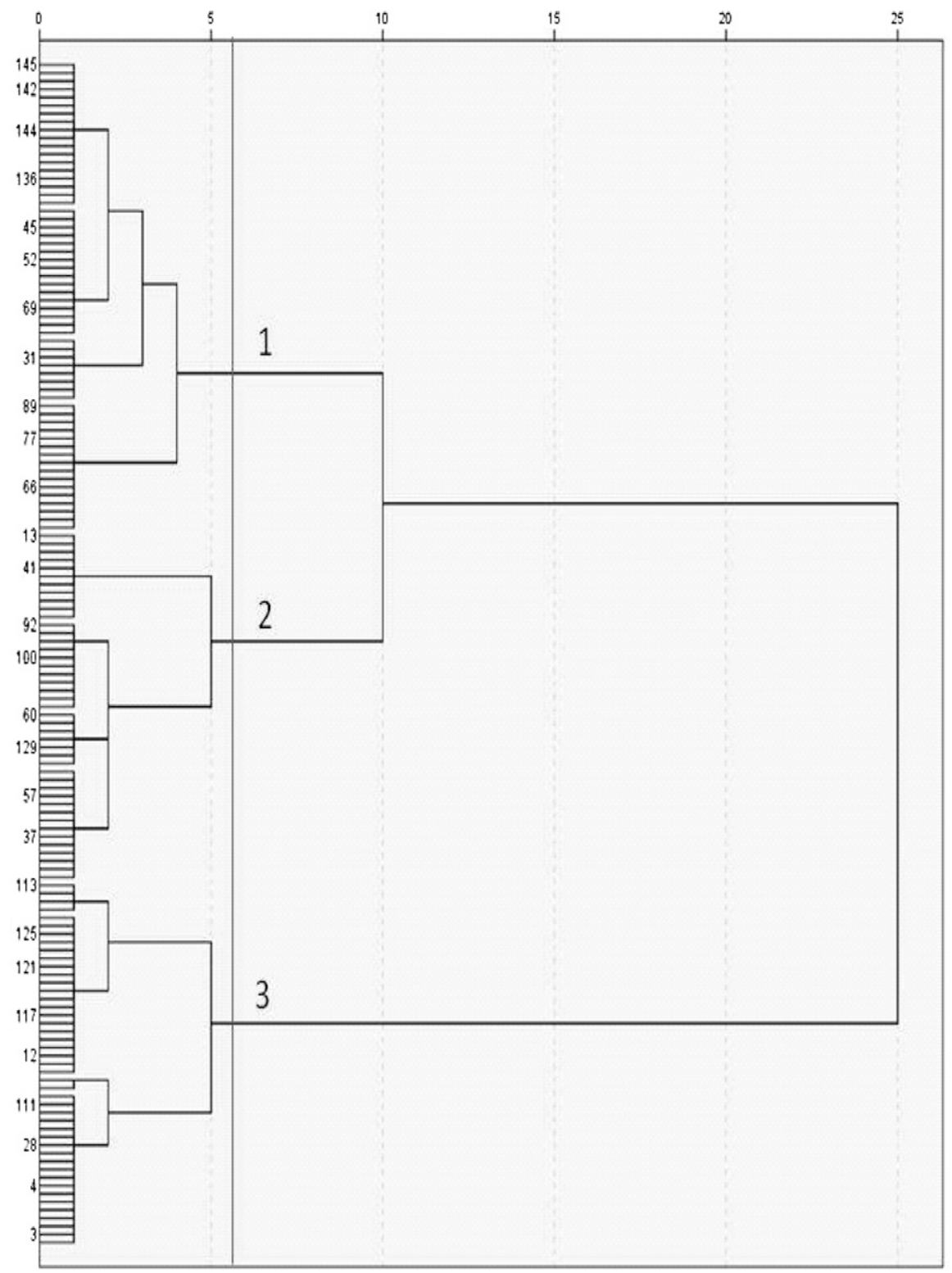

Fig. 1. Dendrogram by the method of Ward of 146 data of collected of Persea schiedeana Nees using variables of soil and climate.

mountainous mesophyll forests, and coniferous forests. The georeferenced sites were located in five physiographic provinces: Sierra Madre Oriental, Neo-Volcanic Axis, the provinces of Sierra Madre del Sur and Sierra Madre Oriental in Mexico with $36.3 \%$ and $28.8 \%$ of the sites, respectively. The types of rock where $P$. schiedeana grew were the ancient rocks of sandy lutite that date from the Paleozoic era in Hidalgo and Puebla (Sierra Madre Oriental), and in Oaxaca (Sierra Madre del Sur). In contrast, the most recent geological records were positioned in the Sierras of Chiapas, Mexico, and Guatemala in the quaternary period on andesite rock in the physiographic provinces of Sierras de Chiapas and Guatemala in the State of Chiapas, Mexico, and in the volcanic tuff in the Neo-Volcanic Axis of the state of Veracruz. The trees were also found on alluvial deposits and palustres of the quaternary period, principally in the Province of Llanura Costera in the Southern Gulf of Mexico in the states of Veracruz and Tabasco. In general, the lower cretaceous calcareous rock type had the most sites referenced with $13 \%$ of the total; this geological unit is located in the Provinces of Sierra Madre Oriental in northern Puebla, Neo-Volcanic Axis in the central part of Veracruz, and in the Sierra Madre del Sur in northern Oaxaca.

The climate types (Köppen modified by García, 1988) where $P$. schiedeana trees were found were warm humid $(31.5 \%)$, warm subhumid $(7.5 \%)$, semiwarm temperate humid $(56.2 \%)$, temperate humid $(3.4 \%)$, and temperate subhumid $(1.4 \%)$. The trees in semiwarm temperate humid climatic conditions were found in the windward zones of Sierra Madre Oriental (Hidalgo and Puebla), in the Neovolcanic axis (Veracruz), and in Sierra Madre del Sur (Oaxaca). With regard to precipitation, all of the $P$. schiedeana trees were distributed in areas that received between $900 \mathrm{~mm}$ (San Bartolomé Zoogocho, Oaxaca) and $5200 \mathrm{~mm}$ (Santiago Comaltepec, Oaxaca) of precipitation. Most of the trees $(17.8 \%)$ received $2200-2400 \mathrm{~mm}$ of annual rainfall in the highland zones of eastern Hidalgo, the center of Veracruz, and north central Oaxaca. Only $11.6 \%$ of the trees received an annual rainfall between 2000 and $2199 \mathrm{~mm}$. All the trees grew in areas that had a mean annual temperature between 15 and $27{ }^{\circ} \mathrm{C}$, with $24.7 \%$ of the total growing in areas with temperatures $20-21^{\circ} \mathrm{C}$. They were found in the windward zone of Sierra Madre Oriental (Hidalgo, Veracruz, and Puebla), Neovolcanic Axis (center of Veracruz), and in Sierra Madre del Sur (northern Oaxaca). The monthly variation of the temperature in the georeferenced sites shows an average minimum monthly value of $12.7^{\circ} \mathrm{C}$ in January and an average maximum monthly value of $29.1^{\circ} \mathrm{C}$ in May.

Persea schiedeana trees were distributed from almost sea level to a little more than $2000 \mathrm{~m}$ in altitude. This species can adapt to various physiographic conditions, geological stratum, and soil types. The trees were primarily located in semiwarm and warm humid areas with a low presence in temperate climates. This suggests low resistance to heavy frost and extended periods of drought, 
conditions that influenced the plant in the course of its evolution (Zunino and Zullini, 2003).

Persea schiedeana was found on 19 different types of soil: $20.5 \%$ of the trees were found on lithosol, $14.4 \%$ on haplic Lithosol soil type was found in the municipalities of Cuetzalan del Progreso (Puebla), Ixtaczoquitlán (Veracruz), Francisco León (Chiapas), Cosolapa (Oaxaca), San Felipe Usila (Oaxaca), and Santa Catarina Juquila (Oaxaca); $53.4 \%$ of the soil texture was fine sand, and $46.6 \%$ medium sand in the upper $30 \mathrm{~cm}$.

Zoning. Three different edapho-climatic clusters were identified (Fig. 1). Cluster 1 encompassed the northern zones of the states of Puebla, Oaxaca, and Chiapas (Fig. 2). Cluster 2 included the eastern part of Hidalgo and its boundaries with Veracruz, the center of Veracruz, and the region of north-central Oaxaca (Fig. 2). Cluster 3 included northern Puebla, Sierra de Zongolica in Veracruz, the north-central and southern parts of phaeozem, and $13 \%$ on chromic vertisol.

Oaxaca, in Tabasco, and western Chiapas (Fig. 2).

The climograph obtained in each cluster (Fig. 3) shows that cluster 1 grouped 58 georeferenced sites with a mean annual precipitation of $2074 \mathrm{~mm}$ and a mean annual temperature of $19.5 \mathrm{C}$. The mean minimum temperature was $15.9^{\circ} \mathrm{C}$ in January, and the mean maximum temperature was of $22.4{ }^{\circ} \mathrm{C}$ in May. The rainiest month was September with $377.2 \mathrm{~mm}$ of precipitation.

Cluster 2 grouped 43 sites, with precipitation of $2287.9 \mathrm{~mm}$ and a mean annual temperature of $23.2^{\circ} \mathrm{C}$. The minimum temperature was $19.8^{\circ} \mathrm{C}$ in January and the maximum was $25.9{ }^{\circ} \mathrm{C}$ in May. The rainiest month was September with $416.6 \mathrm{~mm}$. Cluster 3 grouped 45 sites, with a mean annual temperature of $22.1{ }^{\circ} \mathrm{C}$ and with the highest precipitation in comparison with the other clusters $(4012.6 \mathrm{~mm})$. As in the other clusters, September was the month with highest rainfall $(623.3 \mathrm{~mm})$. January was also the coldest month with $18.8{ }^{\circ} \mathrm{C}$ and May the hottest month with $24.9{ }^{\circ} \mathrm{C}$.

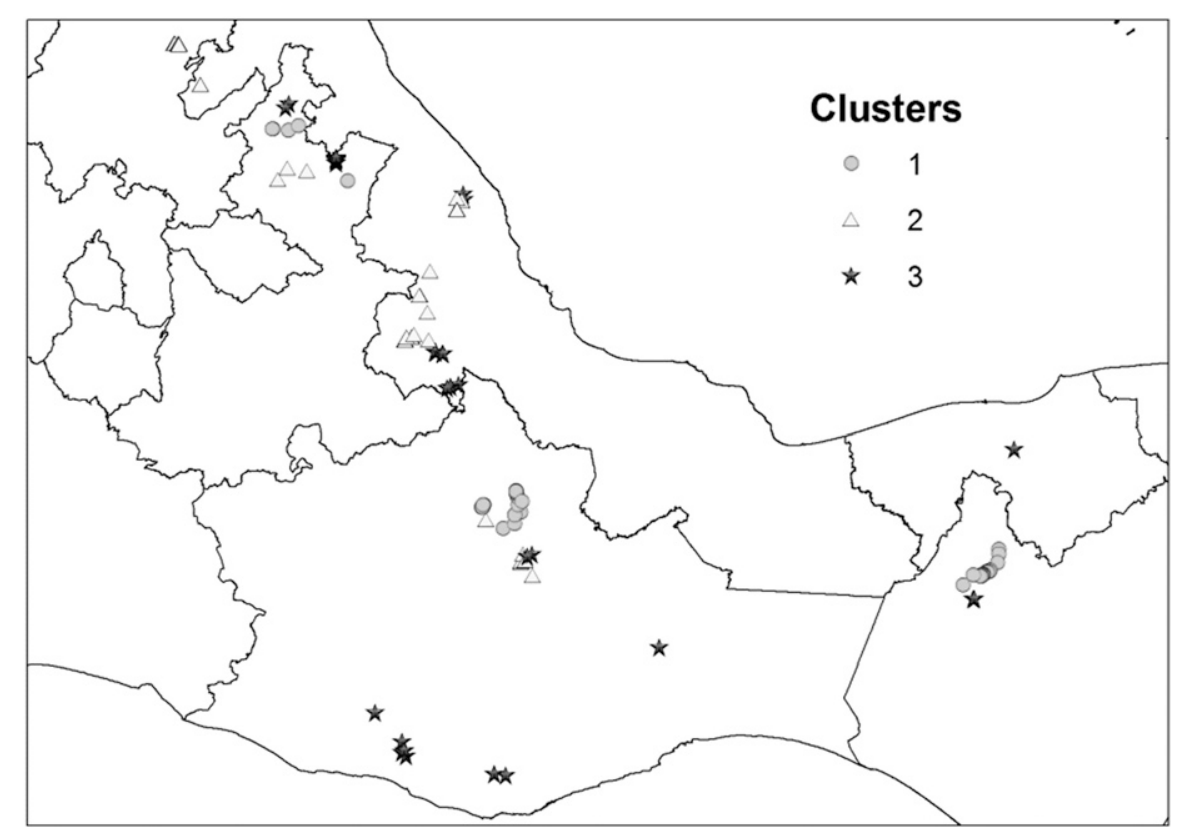

Fig. 2. Spatial distribution of clusters of Persea schiedeana Nees in Mexico.
Cluster 1 had a semiwarm temperate humid climate, whereas clusters 2 and 3 had a warm humid climate. A similar characteristic in all the clusters was the presence of slight dryness in August. The main types of soil in each of the three clusters were lithosol and rendzina (1), andosol humic and vertisol (2), and lithosol, chromic vertisol, and eutric regosol (3).

Potential distribution. The best potential areas for the development of $P$. schiedeana in Mexico, determined using DIVA-GIS ${ }^{\circledR}$ software, were the mountainous zone of the center of Veracruz (Fig. 4) (Municipalities of Zongolica, Amatlán de los Reyes, Cordoba, Tequila, Orizaba, and Ixhuatlán de Café), and the highland zones of medium altitude in the north of Oaxaca. A medium level of aptitude for $P$. schiedeana development was determined to be the zones surrounding the regions with maximum potential in the states of Veracruz and Oaxaca, as well as the northeastern part of the state of Chiapas and the areas where Hidalgo, Veracruz, and Puebla converge (Fig. 4). A low level of aptitude for $P$. schiedeana appears to be in warm conditions in the plain zones of the southern part of Veracruz, the east and west of Tabasco, and southern Campeche (Fig. 4). Avocados growing in warm tropical conditions produce less oil (Gómez-López, 1998); this may be similar for $P$. schiedeana. A fruit sample of $P$. schiedeana harvested in Tabasco had less oleic acid (\%) than fruit from a highland area of Veracruz (Cruz-Castillo et al., 2007). Persea schiedeana trees are scattered in pastures of Tabasco and Chiapas (NahedToral et al., 2013).

The present study provided useful information for specifying zones where $P$. schiedeana could adequately grow alone or in production systems. Furthermore, the clusters could serve as a tool for improving exploration to collect germplasm. For example, to search for rootstocks of $P$. schiedeana with tolerance to phytophthora root rot of avocado, it may be better to explore the high humid areas. Explorations to collect $P$. schiedeana have been carried out in Guatemala, El Salvador, Costa Rica, and Chiapas, Mexico (Schieber and Zentmyer, 1978). Future studies are aimed at evaluating the potential for $P$. schiedeana distribution in stages of climatic
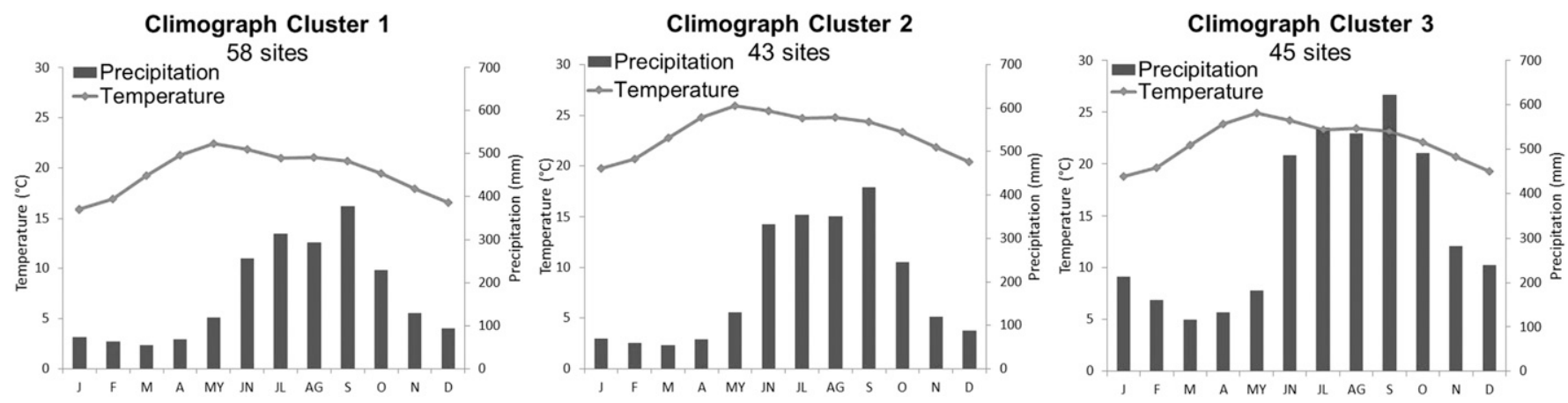

Fig. 3. Climographs of the three different clusters as potential ecological zones of distribution of Persea schiedeana Nees in Mexico. 


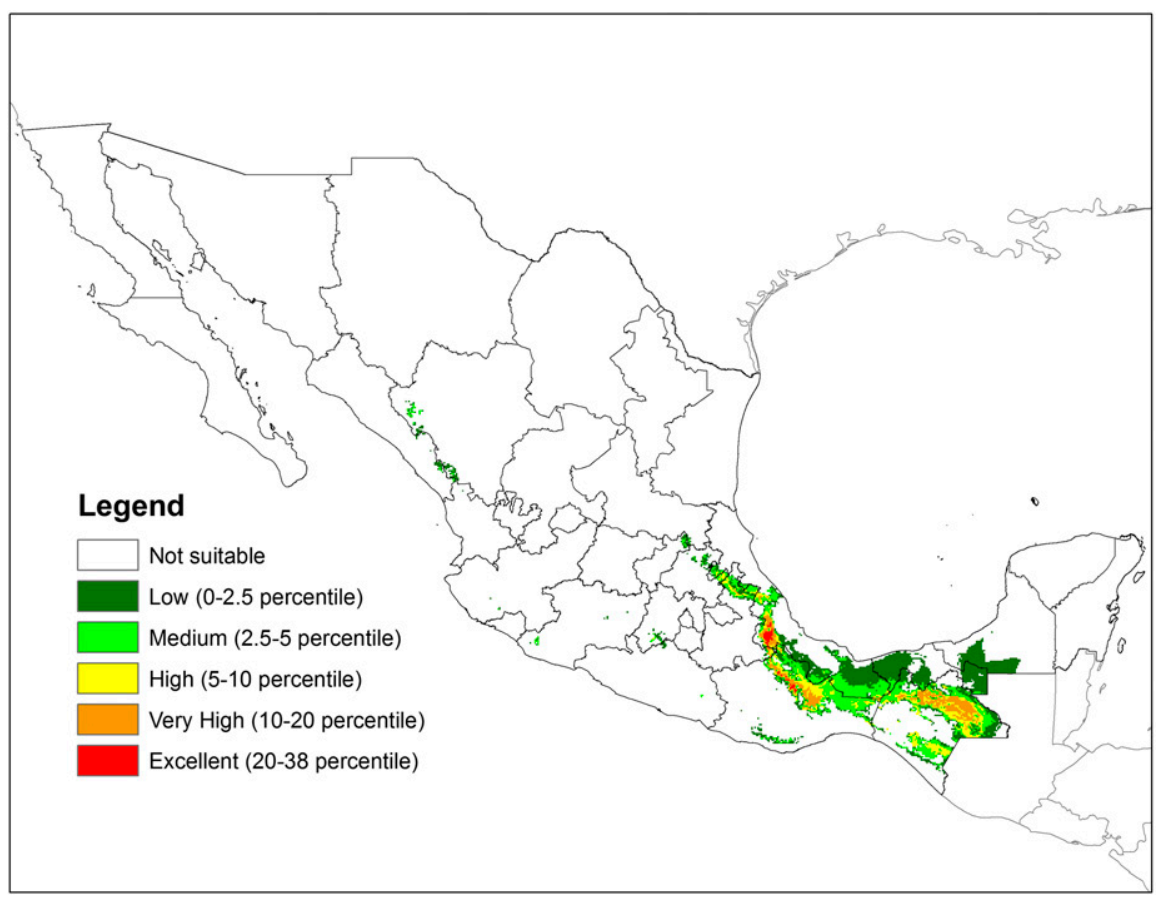

Fig. 4. Potential distribution of Persea schiedeana Nees in Mexico using the WorldClim database.

Table 2. Fatty acids (\%) found in the oil of Persea schiedeana fruits in three different trees. Means of ten fruits for each tree.

\begin{tabular}{lcccccc}
\hline Trees & Palmitic & Palmitoleic & Estearic & Oleic & Linoleic & Linolenic \\
\hline 1 & $19.92 \mathrm{a}$ & $4.65 \mathrm{a}$ & $1.55 \mathrm{~b}$ & $64.66 \mathrm{~b}$ & $5.90 \mathrm{a}$ & $0.58 \mathrm{~b}$ \\
2 & $17.40 \mathrm{~b}$ & $4.70 \mathrm{a}$ & $1.71 \mathrm{a}$ & $67.10 \mathrm{~b}$ & $4.51 \mathrm{~b}$ & $0.48 \mathrm{c}$ \\
3 & $15.45 \mathrm{c}$ & $0.74 \mathrm{~b}$ & $1.25 \mathrm{c}$ & $76.25 \mathrm{a}$ & $3.99 \mathrm{c}$ & $0.75 \mathrm{a}$ \\
\hline
\end{tabular}

Means followed by different letters within each column are significantly different at $P \leq 0.05$ by Tukey's method. change, due to the impact that climatic variability can exert on the phenology and distribution of the species (Monterroso et al., 2012; Tinoco et al., 2011). It is also recommended to carry out ethnobotanic explorations to identify the different uses of $P$. schiedeana in the local communities.

Fatty acid profile of oil of $\mathrm{P}$. schiedeana fruit. It has been reported that the fruit has a percentage of oil between $20 \%$ and $27 \%$ (Joaquín-Martínez et al., 2007). Use of other methods for oil extraction could increase these values. The palmitic, palmitoleic, steafruit oils from three different trees were significantly different $(P \leq 0.05)$ (Table 2$)$. Oleic acid ranged from $64.66 \%$ to $76.25 \%$ $(P \leq 0.05)$, indicating significant differences due to the tree/genotype from which the fruits were collected. The tree with the highest value of oleic acid had the lowest values of all the other fatty acids, with the exception of linolenic acid (Table 2). According to Goldschmidt (2013), P. schiedeana is at an intermediate stage of domestication because although it is grown in home gardens it still remains wide in several tropical zones of Mexico and Central America. The large variability found in the fatty acid composition of the three tree samples indicates that through a selection procedure it could be ric, oleic, linoleic, and linolenic acids in the

likely that, as stated above, the differences in the fatty acid composition of the oils are due to the tree/genotype.

\section{Conclusions}

Persea schiedeana trees were found throughout the Mexican states of Oaxaca, Veracruz, Tabasco, Puebla, Hidalgo, and Chiapas. Three groups of distribution of $P$. schiedeana in Mexico were identified on the basis of temperature and rainfall. These were characterized by semiwarm temperate humid and warm humid climates. The best places for growing $P$. schiedeana are in the mountains of the center of Veracruz and northern Oaxaca. Fruit of $P$. schiedeana, besides being consumed directly, could be used for processed products because it contains a high amount of oleic acid. In future prospections of $P$. schiedeana, the information shown in this article could be considered.

\section{Literature Cited}

Bost, J. 2014. Persea schiedeana: A high oil "cinderella species" fruit with potential for tropical agroforestry systems. Sustainability 6:99-111.

Chehade, A., A.E. Bitar, A. Kadri, E. Choueiri, R. Nabbout, H. Youssef, M. Smeha, A. Awada, Z.A. Chami, E. Dubla, A. Trani, D. Mondelli, and F. Famiani. 2016. In situ evaluation of the fruit and oil characteristics of the main Lebanese olive germplasm. J. Sci. Food Agr. 96:2532-2538.

Coffey, M., F. Guillemet, G. Schieber, and G. Zentmyer. 1988. Persea schiedeana and Martin Grande: The period from 1920 to 1975. Calif Avocado Society Ybk. 72:107-120.

Cruz-Castillo, J.G., O.A. del Ángel-Coronel, J. de la Cruz-Medina, and M.C. Joaquín-Martínez. 2007. Características morfológicas y bioquímicas de frutos de chinene (Persea schiedeana Nees.). Rev. Chapingo. Ser. Hort. 13(2):141-147. produce oils with very high values of oleic acid, which is known to have positive effects on the nutritional value of the oil (Inglese et al., 2011). Indeed, the values were comparable to those of extra-virgin olive oils, for which the Trade Standard of the International Olive Council prescribes that oleic acid must range from $55 \%$ to $83 \%$; values higher than $73 \%$ significantly contribute to the nutritional value of the oil (Inglese et al., 2011). However, in olive oils, the composition of fatty acids can be very different depending on the environmental conditions, cultivar, and ripening stage of the fruit (Chehade et al., 2016; Inglese et al., 2011; Jbara et al., 2010). Also in avocado, the content and the composition of the fatty acids of the oil depend on different factors, such as the cultivar, time of harvest, and postharvest maturation period. Avocados growing in warm tropical conditions produce less oil (Gómez-López, 1998); this may be similar for P. schiedeana. A fruit sample of $P$. schiedeana harvested in Tabasco had less oleic acid (\%) than fruit from a highland area of Veracruz (CruzCastillo et al., 2007). The effects of these factors on the oil of $P$. schiedeana are not known. However, in this study, the trees were in the same area and the fruits appeared to be at a similar stage of ripening; therefore, it is

Del Angel-Coronel, O.A., J.G. Cruz-Castillo, J. De la Cruz, and F. Famiani. 2010. Ripening and physiological changes in the fruit of Persea schiedeana Nees. during the postharvest period. HortScience 45:172-175.

Di Rienzo, J.A., F. Casanoves, M.G. Balzarini, L. Gonzalez, M. Tablada, and C.W. Robledo. 2016. InfoStat versión 2016. Grupo InfoStat, FCA, Universidad Nacional de Córdoba Córdoba, Argentina.

Galindo-Tovar, M.E., N. Ogata-Aguilar, and A.M Arzate-Fernández. 2008. Some aspects of avocado (Persea americana Mill.) diversity and domestication in Mesoamerica. Genet. Resources Crop Evol. 55:441-450.

Gallina, S., S. Mandujano, and A. GonzalezRomero. 1996. Conservation of mammalian biodiversity in coffee plantations of central Veracruz, Mexico. Agrofor. Syst. 33:13-27.

García, E. 1988. Modificaciones al sistema de clasificación climática de Köppen. Instituto de Geografía, Universidad Nacional Autónoma de México, México. 20 Nov. 2013. <http:// www.igeograf.unam.mx/sigg/utilidades/docs/ pdfs/publicaciones/geo_siglo21/serie_lib/modific_ al_sis.pdf $>$.

Global Biodiversity Information Facility (GBIF) 2013. Occurrences of Persea schiedeana Nees. 25 Nov. 2013. <http://www.gbif.org/species/ $3034058>$.

Goldschmidt, E.E. 2013. The evolution of fruit tree productivity: A review. Econ. Bot. 67(1):51-62. 
Gómez, J.D., A.I. Monterroso, and J.A. Tinoco. 2006. Actualización de mapas de cambio climático de la República Mexicana y zonificación de 16 especies forestales de interés para la CONAFOR. Universidad Autónoma Chapingo, Comisión Nacional Forestal, México. (cartografía digital).

Gómez-López, V.M. 1998. Characterization of avocado (Persea americana Mill.) varieties of very low oil content. J. Agr. Food Chem. 46:3643-3647.

Gómez-Pompa, A., T. Krömer, and R. CastroCortés. 2010. Atlas de la flora de Veracruz un patrimonio natural en peligro. Comisión del Estado de Veracruz para la Conmemoración de la Independencia Nacional y la Revolución Mexicana.

Hijmans, R.J., S.E. Cameron, J.I. Grapevine, P.G. Jones, and T. Jarvis. 2005. Very high resolution interpolated climate surfaces global for land areas. Intl. J. Clim. 25:1965-1978.

Ibarra-Manríquez, G., R. Martin, G. Angeles, S. Sinaca-Colín, and M.A. Sinaca-Colín. 1997. Useful plants of the Los Tuxtlas rain forest (Veracruz, Mexico): Considerations of their market potential. Econ. Bot. 51(4):362-367.

INEGI. 2002. Continuo de datos vectoriales de fisiografía de la República Mexicana. Instituto Nacional de Estadística, Geografía e Informática. México. (cartografía digital). 25 Nov. 2013.<http://www.inegi.org.mx/geo/contenidos/recnat/usosuelo/ $>$.

INEGI. 2004. Continuo de datos vectoriales de geología de la República Mexicana. Instituto Nacional de Estadística, Geografía e Informática. México. (cartografia digital). 25 Nov. 2013. <http:// www.inegi.org.mx/geo/contenidos/datosrelieve/ continental/continuoelevaciones.aspx $>$.
INEGI. 2006. Continuo de datos vectoriales de edafología de la República Mexicana. Instituto Nacional de Estadística, Geografía e Informática. México. (cartografia digital). 5 Nov. 2013.<http:// www.inegi.org.mx/geo/contenidos/recnat/edafo$\log \mathrm{a} />$.

INEGI. 2014. Continuo de elevaciones mexicano. Instituto Nacional de Estadística y Geografía. México. (cartografía digital). <http://www.inegi. org.mx/geo/contenidos/datosrelieve/continental/ continuoelevaciones.aspx $>$.

Inglese, P., F. Famiani, M. Servili, S. Esposto, and S. Urbani. 2011. Factors affecting extra-virgin olive oil composition. Hort. Rev. 38:83-147.

Jbara, C., A. Jawhar, Z. Bido, G. Cardone, A. Dragotta, and F. Famiani. 2010. Fruit and oil characteristics of the main Syrian olive cultivars. Ital. J. Food Sci. 22(4):395-400.

Joaquín-Martínez, C., J.G. Cruz-Castillo, J. De la Cruz Medina, and O.A Del Ángel-Coronel. 2007. Distribución ecogeográfica y características del fruto de Persea schiedeana Nees. En Los Tuxtlas, Veracruz, México. Rev. Fit. Mex. 30(4):403-410.

Martínez, M.A., V. Evangelista, F. Basurto, M. Mendoza, and A. Cruz-Rivas. 2007. Flora útil de los cafetales en la sierra norte de Puebla, México. Rev. Mex. Biodivers. 78:15-40.

Melchor-Marroquín, J.I., J.L. Chagoya-Fuentes, and J. Sosa-Azuara. 2014. Estimation of carbon stock in stem wood biomass of several tropical forest species in northern Veracruz, Mexico. Rev. Cient. Biol. Agrop. Tuxpan 2(3):323-327.

Monterroso, A.I., C. Count, C. Gay, J.D. Gómez, and J. López. 2012. Two methods to assess vulnerability to climate change in the Mexican agricultural sector. Mitig. Adapt. Strategies Glob. Change 19(4):445-461.
Nahed-Toral, J., A. Valdivieso-Pérez, R. AguilarJiménez, J. Cámara-Cordova, and D. GrandeCano. 2013. Silvopastoral systems with traditional management in southeastern Mexico: A prototype of livestock agroforestry for cleaner production. J. Clean. Prod. 57:266-279.

Núñez, C.A. 2010. Distribución y caracterización eco-climática del membrillo cimarrón (Ameliancher denticulata (Kunth) Koch) en México. Rev. Chapingo Ser. Hort. 16(3):195-206.

Peacock, A.D., M.D. Mullen, D.B. Ringelberg, D.D. Tyler, D.B. Hedrick, P.M. Gale, and D.C. White. 2001. Soil microbial community responses to dairy manure or ammonium nitrate applications. Soil Biol. Biochem. 33:10111019.

Portarena, S., D. Farinelli, M. Lauteri, F. Famiani, M. Esti, and E. Brugnoli. 2015. Stable isotope and fatty acid compositions of monovarietal olive oils: Implications of ripening stage and climate effects as determinants in traceability studies. Food Control 57:129-135.

Sánchez-Pérez, J.L. 1999. Recursos genéticos de aguacate (Persea americana Mill.,) y especie afines en México. Rev. Chapingo Ser. Hort. Núm. Espe. 5:7-18.

Schieber, E. and G.A. Zentmyer. 1978. Exploring for Persea in Latin America. Calif. Avocado Soc. Ybk 62:60-65.

Tinoco, J.A., J.D. Gómez, and A.I. Monterroso. 2011. Efectos del cambio climático en la distribución potencial del maíz en el estado de Jalisco, México. Terra Latinoam. 29(2):161-168.

Zunino, M. and A. Zullini. 2003. Biogeografía, la dimensión espacial de la evolución. Fondo de Cultura Económica, México. 